\title{
Different ways to implement innovative teaching approaches at scale
}

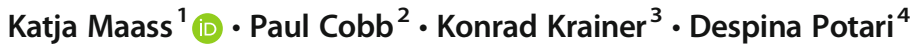

Published online: 21 November 2019

(C) Springer Nature B.V. 2019

\section{Introduction}

Research and experience reveal that innovative teaching approaches promoted by mathematics education researchers differ significantly from the day-to-day practices of teachers in many countries (Van den Akker, Gravemeijer, McKeeney, \& Nieveen, 2006; Boaler, 2008; Burkhardt \& Schoenfeld, 2003; Krainer, 2011; Burkhardt, 2018; Cobb \& Jackson, 2015). As Boaler (2008) puts it: "An elusive and persistent gulf exists between research in mathematics education and the practices of mathematics classrooms, in many countries in the world." (p. 91) This clearly implies that research on implementing teaching approaches effectively is essential if this gulf is to be bridged. These investigations of scaling up should be broad in scope and attend not only to the practices of teachers and researchers, but also to the practices of other important stakeholders including school principals, teacher educators, educational administrators, and policymakers. Furthermore, because teaching contexts differ significantly both within and between regions and countries, it will be important to understand how innovative teaching approaches can be adapted to the local conditions of implementation while preserving their underlying core principles.

In the following paragraphs, we first clarify our understanding of the notion of innovation. Our reading of Fullan's $(2001,2006)$ analyses and our own work lead us to a view that is both optimistic and cautious about addressing the challenges inherent in supporting teachers' development of innovative teaching approaches on a large scale. Innovative teaching approaches are usually introduced in the context of a new curriculum, a teacher education and professional development program, or a combination of the two. However, it is important to stress that innovation is not good for its own sake - not all teaching innovations are improvements. First, in order to distinguish between changes and improvements in teaching, it is

\section{Katja Maass}

maass@ph-freiburg.de

1 University of Education Freiburg, Freiburg, Germany

2 Vanderbilt University, Nashville, TN, USA

3 Alpen-Adria University, Klagenfurth, Austria

4 National and Kapodistrian University of Athens, Athens, Greece 
essential to explicate what is worth knowing and doing mathematically, in the process delineating mathematical learning goals. A teaching innovation is then an improvement if there is evidence (broadly defined) that it can support students' progress towards the identified learning goals more effectively than the typical forms of instruction in a country or region. We acknowledge that this perspective on instructional improvement has a political dimension as there are often conflicts between mathematics education researchers' and policy makers' views about what is worth knowing and doing mathematically. As a consequence, the learning goals on which innovative teaching approaches focus are frequently at odds with national assessments that prioritize procedural competences at the expense of conceptual understanding, procedural fluency, problem solving, and mathematical communication. Second, we also acknowledge that what is clearly an improvement in one context (school, country, etc.) might not be an improvement in another context as the cultural and national priorities in mathematics education may differ, for example, from an emphasis on applications and modeling or on formalization and theory. Third, innovation is not a single act in the sense that you do it and then it is done, but is instead better viewed as a process of supporting teachers' learning that needs to be monitored, analyzed, and revised (perhaps resulting in a preference for the status quo). Fourth, the innovation is necessarily adapted to the local school and classroom context in the process of implementation (Weatherley \& Lipsky, 1977). In this regard, researchers in educational policy view implementation as involving a mutual adaptation between an innovation and the local context (McLaughlin, 1987). Fifth, given that our focus in this special issue is on teaching innovations that have the potential to improve the quality of students' mathematical learning, we are following Elmore (2000) in foregrounding the rationales of innovative teaching approaches, the assessment of feasibility of implementation, evidence of improvement in teaching practices, and attention to contexts of implementation. We aim to promote an orientation to innovation that is open for new possibilities but also emphasizes analysis and a concern for evidence.

Implementing innovative teaching approaches at scale, as an instance of instructional improvement, does not work when it is framed in terms of the transmission of knowledge from researchers or policymakers to teachers (so-called "top-down" approach, see, e.g., Altrichter, Feldman, Posch, \& Somekh, 2008; Ponte, Matos, Guimaraes, Leal, \& Canavarro, 1994; Tirosh \& Graeber, 2003). Teachers clearly need to be seen as crucial agents of change and critical implementers of innovative teaching approaches. If we regard students as inquirybased learners, then teachers who have the appropriate academic background and practical experience also need to be seen as such (see, e.g., Krainer \& Zehetmeier, 2013). However, improving teaching at scale does not work as sporadic efforts by teachers to improve their teaching entirely on their own in isolation from other stakeholders (so-called "bottom-up" approach). Instructional improvement involves substantial teacher learning and requires systematic support, based on clear goals, scientific knowledge, and the monitoring and analysis of progress based on evidence.

Implementing innovations in one classroom can be a challenging endeavor, and it is even more demanding across a whole school. However, it becomes exponentially more challenging when scaling up an innovation aims to reach many schools, a district, or even a state or nation. It is therefore understandable that scaling up has become a concern for mathematics education research during the last 10 years (e.g., Adler, Ball, Krainer, Lin, \& Novotna, 2005). This focus on scaling up is, in part, an effort to address results of international studies like PISA, TIMSS, TALIS or TEDS-M, or of national testing (see, e.g., Krainer, 2015). 
An important dimension of variation concerns the level of scaling up. This can be at a micro-level with a few teachers (e.g., from one school), at a meso-level with tens of teachers (e.g., from different schools in a region), or at a macro-level with hundreds (or even thousands) of teachers (e.g., supporting a reform effort in a district, state, or nation). There is not a strict linearity of these levels: a professional development activity at the micro-level might have a broader influence in the macro-level if the participating teachers shared what they have learned with colleagues. At each of these levels, it is important to take account of different relevant aspects of the context of implementation. These might include students and parents at the micro-level, principals and teacher leaders at the meso-level, and superintendents and policymakers at the macro-level (see, e.g., Krainer, 2015). In addition, relevant aspects of context when scaling up at the national level include to the size of the country. Scaling up, for example, in Spain means something very different to scaling up in Malta. Furthermore, relevant aspects at all three levels include whether there is a national curriculum (as in the UK) or not (as in Germany), the content of the curriculum, the availability of teachers (a surplus or a lack of teachers), and the current types of support on which teachers can draw to improve their teaching.

Against the background of this discussion of innovation and scaling up, we now consider the reasons for the above-mentioned gap between mathematics education research and practice. We will first look at reasons on the side of practice and then take a more critical stand and look at research and the relation between research and practice.

On the side of educational practice, it is challenging for mathematics teachers to change their classroom practice from being an instructor who attempts to directly teach procedures for solving specific, narrowly defined types of tasks, to being a facilitator who aims to support students' development of both conceptual understanding and procedural fluency, their use of multiple representations, their ability to develop and critique mathematical arguments, and so forth (Swan, 2005, 2007). Research-based explanations for the persistence of procedural instruction focus on mathematics teachers' knowledge and beliefs related in particular to the nature of mathematics (Ball, Thames, \& Phelps, 2008; Wilson \& Cooney, 2002). These explanations highlight that many teachers view mathematics as an exact, abstract, deductive discipline with unambiguous solutions (Grigutsch, Raatz, \& Törner, 1998; Maass, 2009). Other explanations focus on the classroom and the existing norms (e.g., students are not used to inquiry-oriented teaching approaches), teachers' community (e.g., limited collaboration with colleagues), school development and leadership (e.g., limited support by the head of school), or the district, national educational, or political context (e.g., mathematics assessments that emphasize procedural competencies over conceptual understanding), the instructional materials available to teachers, and the nature and quality of the supports for teachers' learning (such as professional development, teachers' collaborative meetings) (Cobb, Jackson, Henrick, \& Smith, 2018; Krainer \& Wood, 2008; Skott, 2013; Valero, 2010; Maass, 2009, 2011). Taken together, these various explanations further clarify the challenge of implementing innovating teaching approaches at scale.

Turning now to consider the side of research, we first note that, for various reasons, there is a significant lack of research that can inform practice. Often, research is narrowly focused and gives only limited attention to the complexity of mathematics education in specific contexts (Begg, Davis, \& Bramald, 2003; Boaler, 2008). Further, there is a lack of research that focuses on recurrent problems of practice that are relevant to practitioners. For example, Cobb, Jackson, Henrick, and Smith (2018) point out that there is still little research that can inform 
school and district leaders' decisions about supplemental supports that enable currently struggling students to participate fully in and learn from mainstream instruction that aims at rigorous learning goals. Similarly, research on what specifically school and district leaders might do to support the development of school and district capacity for instructional improvement remains thin (Cobb et al., 2018).

Another important limitation stems from a frequently assumed linear Research-Development-Dissemination model, in which different groups of experts take responsibility for each of these stages with limited communication between them (Begg et al., 2003). Relatedly, the value of Research-Practice Partnerships in which researchers establish genuine partnerships with practitioners and do research with them rather than on them is often underappreciated (Coburn, Penuel, \& Gell, 2013).

Cobb et al. (2018) argue that educational research needs to be at the service of practitioners' instructional improvement efforts if it is to provide much needed empirically grounded guidance. In their view, this requires a change of perspective concerning the relation between research and practice. They discuss and illustrate the value of researchers working with practitioners in ways that prioritize the development of trust, take schools' and districts' current improvement goals, and strategies as a primary point of reference and are sensitive to schools' and districts' capacities and constraints. Collaborating with practitioners in this manner requires researchers to see things from their practitioner colleagues' points of view (Cobb et al., 2018). From this perspective, the reasons for the theory-practice gap on the side of practice that we discussed above are challenges that research needs to address.

\section{Instructional improvement at scale}

\subsection{Current initiatives}

Although the gulf between research and practice is a pressing concern, there are a number of initiatives underway that give rise to optimism. Boaler (2008), for example, describes seven international research studies for which there is evidence of success in influencing mathematics teaching practice on a large scale. Also, building on the recommendation of the Rocard Report (Rocard et al., 2007) and its successor, "Science education for responsible citizenship" (Hazelkorn et al., 2015), the European Commission has funded several dissemination and research projects that aim to support the widespread implementation of inquiry-based learning in STEM education, including Primas (Promoting Inquiry in Mathematics and Science Education Across Europe, 2010-2013), Mascil ("Mathematics and Science for Life", 2013-2016), and Fibonacci (2010-2013). There has also been an increase in the number of large-scale regional and national projects aiming at an improvement of mathematics education, including IMST (Innovations Make School Top, since 1998) and Sinus and Sinus-Transfer (1998-2008) in Europe, MIST (Middle School Mathematics and the Institutional Setting of Teaching, 2006-2017), and PMRR (Practical Measures, Representations, and Routines, 2015-2021) in the US, ETMST (Enhancing the Training of Mathematics and Science Teachers) (2013-2017) in Australia which emphasized cooperation between different stakeholders, the WMCS (Wits Maths Connect Secondary Project, 2010-2014) in South Africa that offers professional development support to the teachers, and the EPMT (Enhancing the Pedagogy of Mathematics Teachers) (2007-2008) professional development project in Singapore that focused on scaling up school-based 
communities of practice. In addition, the International Centre for STEM Education (ICSE, icse.eu) in Freiburg and its consortium were founded in 2017. This large network consists of 14 universities from across Europe that aims to bridge the gulf between research and practice. These initiatives necessarily have to deal with the characteristics of mathematics teaching in specific contexts (e.g., the quality of current student assessments).

Several of these initiatives focus solely on mathematics teaching, whereas others combine several subjects, for example mathematics with science and technology (STEM teaching). There are also instructional improvement projects that have focused on teaching in all subjects. Each of these approaches has advantages and disadvantages. For example, a focus on one single subject (in our case, mathematics) makes it possible to go deep with regard to content (eventually covering several topics such as algebra, calculus, or probability and statistics), but leaves open how the improvement of mathematics teaching might influence all classrooms and school-level developments (where teachers from different disciplines learn from each other). In contrast, initiatives that involve teachers of all subjects open up the possibility of creating joint activities designed to foster the development of a shared vision and of identity at the school level but do not necessarily address content-specific challenges in improving mathematics teaching. Furthermore, both approaches to large-scale implementation leave it to teachers to further develop and integrate the ideas they have learned in professional development settings into their classroom practice in their specific school context.

Although the initiatives mentioned above have made significant contributions, we still have much to learn about how to support the implementation of innovative, research-based approaches to teaching mathematics on a large scale. It is not only that this kind of work is often seen as peripheral to the concerns of mathematics education research, but also that it is very costly in terms of both time and money to conduct large-scale implementation projects, let alone investigate their impact. For example, Maass, Doorman, Jonker, and Wijers (2019) demonstrate how many cycles of design and analysis were required to create innovative classroom and PD materials. Furthermore, there are currently few commonly accepted approaches for designing and for evaluating projects that focus on the large-scale implementation of innovative teaching practices in mathematics (recent approaches are reported, e.g., in Rösken-Winter, Hoyles, \& Blömeke, 2015).

\subsection{Strategies for implementing instructional improvement at scale}

As we have outlined in Sect. 1, supporting improvements in the quality of instruction at scale is very challenging. Concrete strategies that are taken for instructional improvement typically involve some combination of instructional resources, assessment resources, and the provision of support for teachers' learning (e.g., by providing PD courses, PD resources). Several questions arise given the challenges we have discussed.

1. To what extent can resources for mathematics classroom teaching, assessment, and professional development lead to changes in day-to-day classroom teaching?

2. What are the key characteristics of high-quality supports for teachers' learning, such as professional development courses, teacher collaborative meetings, and coaching?

3. How can professional development support be scaled up effectively (e.g., Cobb \& Smith, 2008; Maass \& Artigue, 2013; Rösken-Winter et al., 2015)?

4. What are the critical aspects of school- and system-level contexts that influence the large-scale implementation of innovative teaching approaches, and what are the key 
characteristics of contexts that support teachers' ongoing improvement of their instructional practice (Cobb \& Smith, 2008)? What forms of collaboration are important, when aiming at large scale instructional improvement and how can they be fostered (e.g., Gräsel, Fußangel, \& Pröbstel, 2006; Henrick, Cobb, Penuel, Jackson, \& Clark, 2017; Spieß, 2004)?

5. How can researchers communicate strategies of instructional improvement (e.g., type of resources used, kind of support offered for teachers) to various stakeholders and to the wider public (and discuss with them), so as to foster broad support for the instructional improvement effort and to win more schools and stakeholders for cooperation (European Commission, 2014; European IPR Helpdesk, 2015)?

With reference to question 1, a growing body of research indicates that curricular materials can influence instructional practice and student learning (Ross, McDougall, Hogaboam-Gray, \& LeSage, 2003; Schoen, Cegulla, Finn, \& Fi, 2003; Stein, Smith, Henningsen, \& Silver, 2000; Tarr et al., 2008; Henrick, Appelgate, \& Nazemi, 2018). However, the findings of these studies also indicate that teaching and learning are determined also by a range of other factors in addition to instructional materials. For example, Mischo and Maass (2013) address factors such as teachers' beliefs and personal backgrounds, and their professional development experiences while Ball et al. (2008) and Jackson, Wilhem, and Munter (2018) clarify the relations between teachers' knowledge and perspective, and their classroom practices. Andrews (2013), for his part, identifies national and cultural factors that frame didactic strategies and learning goals in mathematics teaching across four European countries. Thus, although instructional materials are an essential component of effective implementation, they are by no means sufficient.

Turning to question 2, several general features of successful professional development activities are already known. These include direct relevance to teachers' day-to-day classroom practices, the opportunity to discuss problems of practice with colleagues, attention to teachers' beliefs about the nature of mathematics and mathematics teaching, long-term support, and a clear focus on a specific aspect of teaching (Lipowsky \& Rzejak, 2012). But designing professional development courses with these features does not necessarily lead to instructional improvement. There is evidence that teachers do not necessarily implement what they learn in professional development activity in their classrooms (e.g., Maass, 2011; Maass, Swan, \& Aldorf, 2017). Consequently, we need to understand why seemingly high-quality PD is not as effective as we would like. There are a number of findings that demonstrate the influence of teachers' view of what counts as high-quality mathematics teaching, of their view of their students' current mathematical capabilities (Dunlap, 2016), and of aspects of school and school system context including the availability and quality of supports for teachers' learning and of school and system instructional leadership (Cobb et al., 2018).

Turning to question 3, the question of how large numbers of teachers can be supported to improve their instruction is a pressing issue (e.g., Maass \& Artigue, 2013; Rösken-Winter et al., 2015). For example, what are the strengths and weaknesses of so-called "cascade" approaches where course leaders/advisers/coaches or facilitators are educated, and then in turn educate other teachers? It is clear that such approaches require intensive efforts in educating course leaders, and we are still learning what qualifies someone to be an effective course leaders (Ball \& Even, 2009; Robert, 2009; Krainer, Chapman, \& Zaslavsky, 2014), although significant progress has been made in clarifying this issue in recent years (Jackson et al., 2015). A related question concerns the extent to which so-called teacher learning communities are 
effective in supporting teachers' improvement of their instructional practices. Matos, Powell, and Sztajn (2009) link mathematics teachers' learning to school-level communities of practice that are characterized by mutual engagement, a joint enterprise, and a repertoire of knowledge and skills. However, there is strong evidence that, in the US context, such communities are ineffective in supporting the participating teachers in making significant improvements in their classroom practices unless they connect student learning goals, students' thinking, and instruction (Horn, Kane, \& Garner, 2018). As a consequence, effective teacher learning communities are typically led by an accomplished facilitator.

Turning to question 4, we need to acknowledge that regardless of the approach taken, the focus should not only be on providing support for teachers' learning, but also on being responsive to the contexts in which they work (see Sect. 1) For example, Cobb and colleagues (Henrick, Cobb, \& Jackson, 2015) emphasized the importance of relevant stakeholders' active involvement in their large-scale instructional improvement project. Their approach builds on work in educational policy that emphasizes that policy implementation involves active sense making by teachers and school leaders, thereby implicating their understanding of mathematics, teaching, students, and learning. Furthermore, the IMST project in Austria (Krainer \& Zehetmeier, 2013) is investigating the establishment of so-called regional or national centers, networks, or thematic programs in which advisors provide guidance to different stakeholders about a range of dissemination strategies that are both top-down and bottom-up. However, fostering the involvement of school administrators and stakeholders from educational authorities can be very challenging as research and practice are typically separate in these areas (Maass, Wernisch, \& Schäfer, 2015).

Turning to question 5, we have to acknowledge, that though necessary, cooperation (e.g., Spieß, 2004) between different stakeholders (e.g., between teachers, school principals, researchers, and representatives from school authorities and future employers of students) is currently not a reality. For example, although businesses look for employees who can apply mathematics in the context of their work, mathematics education at school is often quite abstract and detached from real life. Cooperation between school practitioners and employers might help resolve this problem. School classes occasionally visit non-formal learning organizations (e.g., museums), but often these remain isolated events that are not connected to either class or students' private lives. A sustainable cooperation between non-formal learning organizations and schools can contribute to the resolution of this issue by addressing their currently conflicting agendas and aims. Cooperation between different stakeholders in mathematics education (schools, educational research, businesses, policymakers, and families) is unlikely to be productive unless their aims for students' learning are aligned (cf. e.g., Spieß, 2004; Gräsel et al., 2006, Dalton, Elias, \& Wandersman, 2007; Nastasi et al., 1998).

A first step in establishing productive collaborations involves developing relations of trust and mutual respect between all partners (cf. e.g., Gräsel et al., 2006; Nastasi et al., 1998). Second, the cooperation needs to be tailored to the needs of the different collaboration partners (European Commission, 2014), as different stakeholders have different foci in their work, operate on different schedules and timelines, and may also have different views on the aims and extent of the cooperation, and on how to cooperate (e.g., Maass et al., 2015). Third, the partners should jointly design cooperation processes that serve all their goals. Last but not least, sustainable cooperation structures that can support the cooperation are also essential. These may include specific conferences designed to foster cooperation (e.g., https://icse. eu/educating-the-educators-iii/), the establishment of regional centers for STEM-education 
(e.g., within IMST, Krainer, Rauch, \& Senger, 2017), or the setting up of networks (e.g., the STEM PD Network, https://icse.eu/international-projects/stem-pd-net/).

We now turn to question 6. Communication refers to the steps taken to spread research findings to a large number of partners (e.g., academic community, teachers, students, and policy-makers). This includes planning how to encourage partners to use research findings in a way it makes sense for them and is appropriate for their local contexts (so-called exploitation and multiplication of research results in additional schools, communities and countries). It also means promoting results of research projects to a wide (possibly non-scientific) audience to raise awareness and demonstrate the benefit of the work for teachers and the wider society (European Commission, 2014; European IPR Helpdesk, 2015). In this regard, the European Commission considers this aspect to be extremely important and evaluates all projects in terms of their dissemination, communication, and exploitation plans (e.g., in H2020, Erasmus+) and has highlighted this issue by providing explicit guidelines (e.g., European Commission, 2014; European IPR Helpdesk, 2015). Dissemination and communication strategies include websites targeted to various stakeholder groups, newsletters, using social media, talks and conferences (for different target groups), face-to-face communication, designing and publicizing materials for teachers, articles in journals for different target groups, and so on. In this respect, using target-oriented language is of utmost importance.

\subsection{A framework for large-scale instructional improvement}

In order to provide an overview of possible approaches to large-scale instructional improvement and to structure further research, the development of a conceptual framework is useful. Maass and Artigue (2013) developed such a framework by analyzing existing projects aimed at overcoming the gulf between research and practice. They distinguish three main categories of approaches to (large scale) implementation: (I) resources, (II) professional development activities, and (III) attending to contexts of implementation. Within each category, they list different aspects that need to be considered. For example, in the case of resources, they distinguish between resources for classroom instruction and for professional development, identify different target groups, and consider key features of particular resources (such as focused on inquiry in mathematics, focused on real-life applications, and so on).

We extend the framework of Maass and Artigue (2013) to summarize the issues that we have discussed in the previous sections. The framework therefore provides an overview of the aspects that might be considered for instructional improvement at scale. We illustrate the relevance of the framework by using it as a tool to discuss the articles in this special issue.

The framework directly relates to the research questions that we raised in Sect. 2.2. The category of resources relates to research question 1, the category of professional development relates to questions 2 and 3, the category of context relates to question 4 , and the categories of cooperation and communication to questions 5 and 6 . Additionally, we have added a category of research based on what we have said in Sect. 1 to emphasize the importance of investigations that focus on problems of practice (see Fig. 1).

All six categories in this framework are connected to each other and are interdependent. For example, professional development initiatives and the professional development resources used in initiatives are obviously interrelated. Similarly, the approach taken to classroom teaching, the PD designed to support it, and the accompanying classroom materials are interdependent (e.g., Prediger, Rösken-Winter, \& Leuders, 2019). Further, research that is at the service of practice and both classroom materials and professional development designed on 


\section{General approaches to instructional improvement at scale}

\begin{tabular}{|c|c|c|}
\hline $\begin{array}{l}\text { I. Research } \\
\text { Perspective on research: } \\
\text { Research on the service of } \\
\text { practitioners; take school } \\
\text { goals at a primary point of } \\
\text { reference, ground it in the } \\
\text { reality of schooling } \\
\text { Research gaps: fill gaps so } \\
\text { that research can offer } \\
\text { guidance on pressing issues } \\
\text { that practitioners routinely } \\
\text { have to address in the } \\
\text { course of their work }\end{array}$ & $\begin{array}{l}\text { II. Resources } \\
\text { - Resources can lead to } \\
\text { instructional improvement } \\
\text { - Different types of resources } \\
\text { (for classroom teaching, } \\
\text { professional development, } \\
\text { different content) } \\
\text { Take into account their } \\
\text { specific target groups and } \\
\text { address their needs. }\end{array}$ & $\begin{array}{l}\text { III. Professional development } \\
\text { - Starts from teachers' needs } \\
\text { and context and is developed } \\
\text { in cooperation with schools } \\
\text { - Different formats: e.g. } \\
\text { workshops, coaching, small } \\
\text { research projects, lesson } \\
\text { study } \\
\text { Takes into account scaling } \\
\text { up: e.g. Cascade, learning } \\
\text { communities, e-learning } \\
\text { communities, regional } \\
\text { centers }\end{array}$ \\
\hline $\begin{array}{l}\text { IV. Context } \\
\text { - Analyses the given context } \\
\text { Takes into account the } \\
\text { different contexts: size of } \\
\text { the country (scaling up in } \\
\text { small countries is different } \\
\text { to large countries), } \\
\text { national curriculum or } \\
\text { state-wise / school-wise } \\
\text { curriculum, content of the } \\
\text { curriculum, teacher } \\
\text { education, cultural } \\
\text { background of the students } \\
\text { and diversity of students }\end{array}$ & $\begin{array}{l}\text { V. Cooperation } \\
\text { Cooperation between different } \\
\text { stakeholders of education is } \\
\text { necessary. } \\
\text { Values \& Attitudes: e.g. } \\
\text { Esteem between all partners, } \\
\text { confidence in cooperation, } \\
\text { openness towards partners } \\
\text { Target-group orientation: e.g. } \\
\text { Anticipate different foci in } \\
\text { work, schedules, goals of } \\
\text { work } \\
\text { Sustainable cooperation } \\
\text { structures can support } \\
\text { cooperation, e.g. Networks, } \\
\text { Conferences }\end{array}$ & $\begin{array}{l}\text { VI. Communication } \\
\text { - Necessary to spread } \\
\text { scientific results and transfer } \\
\text { knowledge to an audience } \\
\text { which can make use of it } \\
\text { (e.g. scientific community, } \\
\text { teachers, students and } \\
\text { policymakers) } \\
\text { To promote research results } \\
\text { to a wide public audience to } \\
\text { raise awareness } \\
\text { Use Target-group-oriented } \\
\text { channels \& language }\end{array}$ \\
\hline
\end{tabular}

Fig. 1 Updated framework for instructional improvement at scale

the basis of such research are interlinked. Also, it is important that researchers who organize professional development courses that aim to support teachers in improving their classroom practices establish genuine partnerships with the practitioners (i.e., do research with them rather than on them) (Tseng \& Nutley, 2014). Partnerships of this type are grounded in trust and mutual respect, and aim to address agreed-upon problems of practice by conducting methodologically rigorous investigations that are relevant and timely for the participating practitioners, and support them in achieving their goals (Henrick et al., 2017). Last but not least, if a researcher aims at cooperation with policymakers, the communication with them should be target-group oriented, thereby linking these aspects as well.

The framework is open to revision, elaboration, extension, and improvement, while it also gives insight into currently relevant aspects of instructional improvement. Although not every category is relevant in every context, the framework gives an idea of the categories that might be potentially relevant in different contexts. 


\section{The contributions of this volume}

\subsection{Professional development}

Three of the papers aim at scaling up by focusing on professional development (category II).

The paper by Heck, Plumley, Stylianou, Smith, and Moffett, "Scaling Innovative Learning in Mathematics: Exploring the effect of different professional development approaches on teacher knowledge, beliefs, and instructional practice", addresses the category of professional development in our framework, and more concretely professional learning experiences (PLEs). The purpose of the study focuses on early algebra knowledge and classroom practice and investigates the extent to which three different approaches for engaging teachers in PLEs might enable the field to scale up innovative instructional approaches in a sustainable manner. The three PLE formats are (1) a facilitated summer workshop, (2) a multimedia course completed on teachers' own time, and (3) learning resources provided in the algebra curriculum unit that teachers used individually. The findings indicate that all three PLE formats had a positive impact on teachers' professional learning in relation to the development of their knowledge and instructional practices.

The paper by Clark-Wilson and Hoyles, "A research-informed web-based professional development toolkit to support technology-enhanced mathematics teaching at scale", reports on new technology-enhanced curriculum units for lower secondary mathematics that embed dynamic mathematical technology (DMT). These units combine web-based DMT, student and teacher materials, and professional development that focused on developing teachers' mathematical knowledge and pedagogy for teaching with technology. Thus, the study addresses the categories professional development and resources (Fig. 1). As part of their work, the authors developed a professional development toolkit that includes a lesson planning template and links to a teacher online-community, videos outlining highlighting the important mathematical ideas in students' tasks, video clips of teachers' mediation of the dynamic mathematics technology, and examples of typical students' written work. The results of the piloting of the toolkit indicate that it has the potential to overcome teacher-reported barriers to their use of dynamic mathematical technology.

The contribution of these two studies to knowledge about scaling up professional development is to demonstrate that there is not a single effective approach to professional development. Heck et al. show that flexibility in terms of the available resources and the context is an important feature of professional development programs. Clark-Wilson and Hoyles also enrich their program with resources including a lesson planning template, videos, and pupils' written work and take into account the context by setting up an online-community.

Prediger, Fischer, Selter, and Schöber also combine the aspects professional development and resources, and attended to the context of implementation in their paper "Combining material- and community-based implementation strategies for scaling up: The case of supporting low-achieving middle school students". Their community-based strategy emphasizes the value of professional learning communities that are embedded in school and district settings. Their strategy includes well-designed teaching materials, which they view as catalysts for implementing innovative teaching approaches in many classrooms. Their implementation project combines both categories of the framework and also takes account of the school and district levels of the school system. The goal of the project is to help teachers better support currently low-achieving students at the beginning of German secondary school (Grades 5 and 6). The results of the quasi- 
experimental study that they report in this article again show that such a combination of strategies can be effective: the participating students had higher learning gains than the control group. A follow-up analysis provides insights into the interplay of community aspects, institutional backgrounds, and the teaching materials.

In summary, all three papers provide evidence that focusing on one category of the framework (resources, professional development, or involving the context) is not sufficient and that it is necessary to also provide resources and take into account the context.

\subsection{Implementation}

In two other papers, the primary focus is on attending to the context of implementation (category III):

In their paper "Educational policy to improve mathematics instruction at scale: Conceptualizing contextual factors turns", Ryve and Hemmi draw on data collected during a large-scale project carried out during 2012-2017. They analyze Swedish educational contexts and conceptualize contextual factors based on the approach of Cobb and Jackson (2012). In addition to acknowledging explicit contextual factors such as ongoing policies and practices, they analyze underlying, more implicit contextual factors of (1) the positioning of teachers within the educational system, (2) the positioning of teachers in the classroom, and (3) traditions of visible and invisible pedagogy. The authors examine how these three contextual factors influenced the participating teachers' use of curriculum materials. Ryve and Hemmi make us aware that for large-scale implementation efforts to have a positive impact on mathematics teaching and learning, curriculum designers, mathematics teacher educators and researchers need to attend to these contextual factors, thereby emphasizing the relevance of the context as well as the value of cooperation between different stakeholders.

The paper by Krainer, Zehetmeier, Hanfstingl, Rauch, and Tscheinig, "Insights into scaling up a nationwide learning and teaching initiative on various levels", reports a meta-study of a nationwide scaling-up initiative in Austria in which teachers were treated as autonomous professionals. The study uses diffusion of innovation theory and self-determination theory as lenses to explore scaling up processes at the teacher, school, regional, and the national levels. Krainer et al. aimed to identify both the factors that fostered effective scaling up and the challenges that arose in the course of their initiative. The study shows, among other things, that (a) resources are not only relevant for teachers (external support by teacher educators), but also for the researchers (lack of resources in teacher education and research, in particular in primary education); (b) professional development across levels of the system is important (teacher, schools, regional, and the national levels, and to some extent also the international level); (c) the value of balancing bottom-up and top-down approaches; and (d) the interplay between these levels is important, in particular an interconnection between individual and organizational learning that balances the interests of practice, educational policy, and teacher education and research.

From these two papers, we learn details about what it means to attend to the context of implementation by looking beyond curricula and assessments by, for example, attending to the positioning of teachers within the educational systems and the classroom. Krainer et al. demonstrate the importance of attending to multiple levels of the education system (from the classroom to the system level) and of ensuring that the improvement initiative is coordinated across the various levels. 


\subsection{Cooperation and communication}

Cooperation is the main focus of the paper by Potari, Psycharis, Sakonidis, and Zachariades "Collaborative design of a reform-oriented mathematics curriculum: contradictions and boundaries across teaching, research and policy". The paper uses Activity Theory to analyze the process of designing a national mathematics curriculum and employs the constructs of boundary crossing and boundary object to study the interaction of three activity systems: mathematics teaching, mathematics education research, and educational policy. The focus is on the collaboration of members of the design team from each of these areas and highlights (a) the contradictions that emerged during interactions between members of the design team and how these contradictions were related to the elements of the three activity systems and (b) how the team members dealt with these contradictions between the three activity systems. The study contributes to our understanding of the process of mathematics curriculum development and of the conditions that may support or hinder the development of mathematics teaching that involves facilitating students' mathematical understanding. In terms of the collaboration between educational policy, research, and teaching, the study illustrates that there are likely to be tensions and that the process of resolving them involves both dialogic negotiation among the participants and the contributions of brokers who move between policy, research, and teaching.

The paper by Drijvers, Kodde-Buitenhuis, and Doorman, "Assessing mathematical thinking as part of curriculum reform in the Netherlands", focuses on the category of resources, more specifically assessment resources. Assessment is a crucial factor in the implementation of curriculum reform initiatives. However, we have much to learn about how curriculum changes can be reflected adequately in assessment, particularly if the reform concerns process skills. Drijvers et al. investigated this issue in the case of assessing mathematical thinking in a mathematics curriculum reform effort for 15-18-year-old students in the Netherlands. These reform curricula were field tested in pilot schools for 6 years (2011-2017) while other schools used their regular curricula. The research question addressed was whether and how this reform was reflected in national examination papers, and in student performance on the corresponding assignments. The primary contribution of the paper is its analysis of the relations between national curricula, assessments, and students' mathematical thinking. It indicates the impact of top-down educational innovations on assessment resources and day-to-day teaching and learning.

The category of communication is apparent in many of the papers. Prediger et al. provide insight into the value of collaboration between teachers in their community-based work and also illustrate the importance of cooperation and communication with school principals and school district leaders. For their part, Clark-Wilson and Hoyles highlight the importance of communicating with school leadership and departmental colleagues, as well as with teachers in order to recruit additional teachers to participate in the project. Ryve and Hemmi refer to the necessity to communicate with policymakers, municipality leaders, principals, and teachers, and Krainer et al. emphasize that communication needs to target different stakeholders and should be tailored to their different interests and needs. For their part, Potari et al. illustrate the types of contradictions that can emerge when educational policymakers, teachers, and mathematics education researchers collaborate, and the importance of boundary crossings in resolving these contradictions.

Overall, this special issue provides valuable insights into important aspects of the process of scaling-up innovative teaching approaches. School and system level context emerges as an 
important factor that needs to be considered when attempting to scale up teaching approaches. For example, the contextual factors are crucial in the way that professional development works in Sweden, in the process of developing the new national curriculum in Greece, in the PD activities and resources in the US and in the UK, in the links between assessment procedures and curriculum resources in the Netherlands, and in scaling up processes in Austria and Germany. Collaboration and communication between stakeholders appear to be important in addressing contextual factors as well as in making the innovative teaching approaches relevant to classroom teachers. Although a range of different resources is described in the studies reported in this special issue, taken together, the findings indicate that the transformation of resources from the design to the actual implementation in professional development and in the classroom is a complex process. The findings also indicate that context is an important factor that influences the effectiveness of professional development initiatives. Finally, the studies illustrate that research questions salient to large-scale implementation efforts are of a more systemic character and require complex methodological approaches to address them adequately.

In considering the relevance of the studies of this special issue to different stakeholders, we note that the findings may make policymakers coming to appreciate the way that research, resources, professional development, communication, and collaboration are interrelated. In addition, the studies in this special issue challenge researchers to make the improvement of teaching and learning at scale an explicit focus of investigation and to develop theoretical and analytical frameworks that will enable them to investigate the complex, multi-level processes involved. The studies also illustrate how this challenge might begin to be addressed, in the process-making research more relevant to practitioners.

\section{References}

Adler, J., Ball, D., Krainer, K., Lin, F. L., \& Novotna, J. (2005). Reflections on an emerging field: Researching mathematics teacher education. Educational Studies in Mathematics, 61(3), 359-381.

Altrichter, H., Feldman, A., Posch, P., \& Somekh, B. (2008). Teachers investigate their work: An introduction to action research across the professions (2nd ed.). London, New York: Routledge.

Andrews, P. (2013). Comparative studies of mathematics teaching: Does the means of analysis determine the outcome? ZDM Mathematics Education, 45, 133-144.

Ball, D. L., \& Even, R. (2009). Strengthening practice in and research on the professional education. In R. Even \& D. Loewenberg Ball (Eds.), The professional education and development of teachers of mathematics - the 15th ICMI Study (pp. 255-260). New York, NY: Springer.

Ball, D. L., Thames, M. H., \& Phelps, G. (2008). Content knowledge for teaching: What makes it special? Journal of Teacher Education, 59, 389-407.

Begg, A., Davis, B., \& Bramald, R. (2003). Obstacles to the dissemination of mathematics education research. In A. J. Bishop, M. A. Clements, C. Keitel, J. Kilpatrick, \& F. K. S. Leung (Eds.), Second International Handbook of Mathematics Education (pp. 593-634). Dordrecht, the Netherlands: Kluwer Academic Publishers.

Boaler, J. (2008). Bridging the gap between research and practice: International examples of success. In M. Menghini, F. Furinghetti, L. Giarcardi, \& F. Arzarella (Eds.), The first century of the international commission on mathematics instruction (1908-2008): Reflecting and shaping the world of mathematics education. Instituto della Enciclopedia Italiana foundata da Giovanni Treccani: Rome, Italy.

Burkhardt, H. (2018). Towards research-based education. Retrieved from https://www.mathshell. com/papers/pdf/hb_2018_research_based_education.pdf.

Burkhardt, H., \& Schoenfeld, A. (2003). Improving educational research: Towards a more useful influential and better-funded enterprise. Educational Researcher, 32(9), 3-14.

Cobb, P., \& Jackson, K. (2012). Analyzing educational policies: A learning design perspective. The Journal of the Learning Sciences, 21(4), 487-521. 
Cobb, P., \& Jackson, K. (2015). Supporting teachers' use of research-based instructional sequences. ZDM Mathematics Education, 47, 1027-1038.

Cobb, P., Jackson, K., Henrick, E., \& Smith, T. M. (2018). Putting the pieces together. In P. Cobb, K. Jackson, E. Henrick, T. M. Smith, \& the MIST Team (Eds.), Systems for instructional improvement: Creating coherence from the classroom to the district central office (pp. 221-240). Cambridge, MA: Harvard Education Press.

Cobb, P., \& Smith, T. (2008). District development as a means of improving mathematics teaching and learning at scale. In K. Krainer \& T. Wood (Eds.), International handbook of mathematics teacher education: Vol. 3. Participants in mathematics teacher education: Individuals, teams, communities and networks (pp. 231254). Rotterdam, the Netherlands: Sense.

Coburn, C. E., Penuel, W. R., \& Gell, K. E. (2013). Research-practice partnerships: Strategies for leveraging research for educational improvement in school districts. New York, NY: William T. Grant Foundation.

Dalton, J. H., Elias, M. J., \& Wandersman, A. (2007). Community psychology: Linking individuals and communities. Belmont, CA: Thomson-Wadsworth.

Dunlap, C. J. (2016). Examining how school settings support teachers' improvement of their classroom instruction. (Doctoral dissertation), Vanderbilt University, Nashville, TN.

Elmore, R. F. (2000). Building a new structure for school leadership. Washington, DC: Albert Shanker Institute.

European Commission. (2014). Communicating EU research and innovation guidance for project participants. http://ec.europa.eu/research/participants/data/ref/h2020/other/gm/h2020-guide-comm_en.pdf. Accessed April 2019.

European IPR Helpdesk. (2015). The Plan for the exploitation and dissemination of results in Horizon 2020. https://www.iprhelpdesk.eu/sites/default/files/newsdocuments/Fact-Sheet-Plan-for-the-Exploitation-andDissemination-of-Results-H2020.pdf. Accessed April 2019.

Fullan, M. (2001). The new meaning of educational change (3rd ed.). New York, NY: Teachers College Press.

Fullan, M. (2006). The future of educational change: System thinkers in action. Journal of Educational Change, 7, 113-122.

Gräsel, C., Fußangel, K., \& Pröbstel, C. (2006). Lehrkräfte zur Kooperation anregen - eine Aufgabe für Sisyphos? Zeitschrift für Pädagogik, 52(2), 205-219.

Grigutsch, S., Raatz, U., \& Törner, G. (1998). Einstellung gegenüber Mathematik bei Mathematiklehrern. JMD, 19(1), 3-45.

Hazelkorn, E., Ryan, C., Beernaert, Y., Constantinou, C., Deca, L., Grangeat, M., Karikorpi, M., Lazoudis, A., Casulleras, R., \& Welzel-Breuer, M. (2015). Science education for responsible citizenship. Retrieved from http://ec.europa.eu/research/swafs/pdf/pub_science_education/KI-NA-26-893-EN-N.pdf on 09 September 2015.

Henrick, E. C., Appelgate, M., \& Nazemi, M. (2018). Instructional materials as tools for instructional improvement. In P. Cobb, K. Jackson, E. Henrick, T. Smith, \& the MIST team (Eds.), Systems for instructional improvement: Creating coherence from the classroom to the district central office (pp. 149-158). Cambridge, MA: Harvard Education Press.

Henrick, E. C., Cobb, P., \& Jackson, K. (2015). Educational design to support dystem-wide instructional improvement. In A. Bikner-Ahsbahs, C. H. Knipping, \& N. Presmeg (Eds.), Approaches to qualitative research in mathematics education. examples of methodology and methods (pp. 497-530). (Springer Series: Advances in Mathematics Education)). Dordrecht, the Netherlands: Springer.

Henrick, E. C., Cobb, P., Penuel, W., Jackson, K., \& Clark, T. (2017). Assessing research-practice partnerships: Five dimensions of effectiveness. New York, NY: W. T. Grant Foundation.

Horn, I. S., Kane, B. D., \& Garner, B. (2018). Teacher collaborative time: Helping teachers make sense of ambitious teaching in the context of their schools. In P. Cobb, K. Jackson, E. Henrick, T. M. Smith, \& the MIST Team (Eds.), Systems for instructional improvement: Creating coherence from the classroom to the district central office (pp. 93-112). Cambridge, MA: Harvard Education Press.

Jackson, K., Cobb, P., Wilson, J., Webster, M., Dunlap, C., \& Appelgate, M. (2015). Investigating the development of mathematics leaders' capacity to support teachers' learning on a large scale. ZDM, 47, 93104.

Jackson, K., Wilhem, A. G., \& Munter, C. (2018). Specifying goals for students' mathematical learning and the development of teachers' knowledge, perspective, and practices. In P. Cobb, K. Jackson, E. Henrick, T. M. Smith, \& the MIST Team (Eds.), Systems for instructional improvement: Creating coherence from the classroom to the district central office (pp. 43-64). Cambridge, MA: Harvard Education Press.

Krainer, K. (2011). Teachers as stakeholders in mathematics education research. In B. Ubuz (Ed.), Proceedings of the 35th conference of the international group for the psychology of mathematics education (vol. 1, pp. 4762). Ankara, Turkey: Middle East Technical University.

Krainer, K. (2015). Reflections on the increasing relevance of large-scale professional development. ZDM - The International Journal on Mathematics Education, 47(1), 143-151. 
Krainer, K., Chapman, O., \& Zaslavsky, O. (2014). Mathematics teacher educator as learner. In S. Lerman (Ed.), Encyclopedia of Mathematics Education (pp. 431-434). Dordrecht, Heidelberg, New York \& London: Springer Online: http://link.springer.com/referencework/10.1007/978-94-007-4978-8

Krainer, K., Rauch, F., \& Senger, H. (2017). The IMST project: Reflections on a nation-wide initiative fostering educational innovation. In B. Hanfstingl \& P. Ramalingam (Eds.), Educational action research. Austrian model to India (pp. 16-34). I.K. International Publishing House Pvt. Ltd..

Krainer, K., \& Wood, T. (Eds.). (2008). International handbook of mathematics teacher education, Participants in mathematics teacher education: Individuals, teams, communities and networks (vol. 3). Rotterdam, the Netherlands: Sense Publishers.

Krainer, K., \& Zehetmeier, S. (2013). Inquiry-based learning for students, teachers, researchers, and representatives of educational administration and policy: Reflections on a nation-wide initiative fostering educational innovations. ZDM Mathematics Education, 45(6), 875-886.

Lipowsky, F., \& Rzejak, D. (2012). Lehrerinnen und Lehrer als Lerner - Wann gelingt der Rollentausch? Merkmale und Wirkungen wirksamer Lehrerfortbildungen. Schulpädagogik heute, 3(5), 1-17.

Maass, K. (2009). What are teachers' beliefs about effective mathematics teaching? In J. Cai, G. Kaiser, B. Perry, \& N.-Y. Wong (Eds.), Effective mathematics teaching from teachers' perspectives: National and crossnational studies (pp. 141-162). Rotterdam, the Netherlands: Sense Publishers.

Maass, K. (2011). How can teachers' beliefs affect their professional development? ZDM Mathematics Education, 43(4), 573-586.

Maass, K., \& Artigue, M. (2013). Implementation of inquiry-based learning in day-to-day teaching: A synthesis. ZDM Mathematics Education, 45(6), 779-795.

Maass, K., Doorman, M., Jonker, V., \& Wijers, M. (2019). Promoting active citizenship in mathematics teaching. ZDM Mathematics Education, 51(7), 1-13. https://doi.org/10.1007/s11858-019-01048-6

Maass, K., Swan, M., \& Aldorf, A. (2017). Mathematics teachers' beliefs about inquiry-based learning after a professional development course - An International Study. Journal of Education and Training Studies, 5(9), 1-17. https://doi.org/10.11114/jets.v5i9.2556

Maass, K., Wernisch, D., \& Schäfer, E. (2015). Conference outcomes and conclusions. In K. Maass, G. Törner, D. Wernisch, E. Schäfer, \& K. Reitz-Koncebovski (Eds.), Educating the educators: International approaches to scaling up professional development in mathematics and science education. Verlag für wissenschaftliche Texte und Medien: Münster, Germany.

Matos, J. F., Powell, A., \& Sztajn, P. (2009). Mathematics teachers' professional development: Processes of learning in and from practice. In R. Even \& D. Loewenberg Ball (Eds.), The professional education and development of teachers of mathematics (pp. 167-184). New York, NY: Springer.

McLaughlin, M. W. (1987). Learning from experience: Lessons from policy implementation. Educational Evaluation and Policy Analysis, 9, 171-178.

Mischo, C., \& Maass, K. (2013). The effect of teacher beliefs on student competence in mathematical modeling An intervention study. Journal of Education and Training Studies, 1(1), 19-38.

Nastasi, B. K., Varjas, K., Schensul, S. L., Silva, K. T., Schensul, J. J., \& Ratnayake, P. (1998). The participatory intervention model: A framework for conceptualizing and promoting intervention acceptability. School Psychology Quarterly, 15(2), 207-232.

Ponte, J., Matos, J., Guimaraes, H., Leal, L., \& Canavarro, A. (1994). Teachers' and students' views and attitudes towards a new mathematics curriculum: A case study. Educational Studies in Mathematics, 26(4), 347-365.

Prediger, S., Rösken-Winter, B., \& Leuders, T. (2019). Which research can support PD facilitators? Strategies for content-related PD research in the Three-Tetrahedron Model. Journal of Mathematics Teacher Education, 22, 407-425. https://doi.org/10.1007/s10857-019-09434-3

Robert, A. (2009). Learning in and from practice: Comments and reflections. In R. Even \& D. Loewenberg Ball (Eds.), The professional education and development of teachers of mathematics (pp. 227-230). New York, NY: Springer.

Rocard, M., Csermely, P., Jorde, D., Lenzen, D., Walberg-Henriksson, H., \& Hemmo, V. (2007). Science education now: A renewed pedagogy for the future of Europe. Brussels, Belgium: European Commission.

Rösken-Winter, B., Hoyles, C., \& Blömeke, S. (2015). Evidence based CPD: Scaling up sustainable interventions. ZMD Mathematics Education, 47(1), 1-12.

Ross, J. A., McDougall, D., Hogaboam-Gray, A., \& LeSage, A. (2003). A survey measuring elementary teachers' implementation of standards-based mathematics teaching. Journal for Research in Mathematics Education, 34(4), 344-363.

Schoen, H., Cegulla, K., Finn, K., \& Fi, C. (2003). Teacher variables that relate to student achievement when using a standards-based curriculum. Journal for Research in Mathematics Education, 34(3), 228-259.

Skott, J. (2013). Understanding the role of the teacher in emerging classroom practices: Searching for patterns of participation. ZDM Mathematics Education, 45, 547-599. 
Spieß, E. (2004). Kooperation und Konflikt. In H. Schuler (Ed.), Organisationspsychologie - Gruppe und Organisation (pp. 193-250). Göttingen, Germany: Hogrefe.

Stein, M., Smith, M., Henningsen, M., \& Silver, E. (2000). Implementing standards-based mathematics instruction: A casebook for professional development. New York, NY: Teachers College Press.

Swan, M. (2005). Improving Learning in Mathematics: Challenges and Strategies. Sheffield, UK: Teaching and Learning Division, Department for Education and Skills Standards Unit.

Swan, M. (2007). The impact of task-based professional development on teachers' practices and beliefs: A design research study. Journal of Mathematics Teacher Education, 10(4-6), 217-237.

Tarr, J. E., Reys, R. E., Reys, B. J., Chavez, O., Shih, J., \& Osterlind, S. J. (2008). The impact of middle-grades mathematics curricula and the classroom learning environment on student achievement. Journal for Research in Mathematics Education, 39, 247-280.

Tirosh, D., \& Graeber, A. O. (2003). Challenging and changing mathematics teaching practises. In A. J. Bishop, M. A. Clements, C. Keitel, J. Kilpatrick, \& F. K. S. Leung (Eds.), Second international handbook of mathematics education (pp. 643-688). Dordrecht, the Netherlands: Kluwer Academic Publishers.

Tseng, V., \& Nutley, S. (2014). Building the infrastructure to improve the use and usefulness of research in education. In K. Finnigan \& A. Daly (Eds.), Using research evidence in education: From the schoolhouse door to Capitol Hill. Policy implications of research in education (pp. 163-175). Switzerland: Springer International Publishing.

Valero, P. (2010). Mathematics education as a network of social practices. In V. Durand-Guerrier et al. (Eds.), Proceedings of the Sixth Congress of the European Society for Research in Mathematics Education (pp. LIV-LXXX). Lyon, France: Institut National de Récherche Pédagogique.

Van den Akker, J., Gravemeijer, K. P. E., McKeeney, S., \& Nieveen, N. (2006). Introducing educational design. In J. V. D. Akker, K. Gravemeijer, S. M. Keeney, \& N. Nieveen (Eds.), Educational design research (pp. 37). Routledge Chapman \& Hall: Oxford, UK.

Weatherley, R., \& Lipsky, M. (1977). Street-level bureauctrats and institutional innovation: Implementing special education reform. Harvard Educational Review, 47, 171-197.

Wilson, M., \& Cooney, T. J. (2002). Mathematics teacher change and development. The role of beliefs. In G. C. Leder, E. Pehkonen, \& G. Törner (Eds.), Beliefs: A hidden variable in mathematics education? (pp. 127148). Dordrecht, the Netherlands: Kluwer Academic Publishers.

Publisher's note Springer Nature remains neutral with regard to jurisdictional claims in published maps and institutional affiliations. 